[Radiocarbon, Vol. 18, No. 3, 1976, P. 362-370]

\title{
UNIVERSITY OF GEORGIA RADIOCARBON DATES V
}

\author{
JOHN E NOAKES and BETTY LEE BRANDAU \\ Geochronology Laboratory, 110 Riverbend Road \\ University of Georgia, Athens, Georgia 30602
}

The following list of dates is compiled from samples prepared and catalogued since publication of our last date list (R, 1975, v 17, p 99-111). The counting equipment and operating procedures are the same. Ages are quoted with a $l_{\sigma}$ counting error which includes statistical variation of the sample count as well as for background and standard, using AD 1950 as the reference year and $95 \%$ NBS oxalic acid for ${ }^{14} \mathrm{C}$ dating as the standard. The half-life value used is 5570 years.

\section{ACKNOWLEDGMENTS}

We gratefully acknowledge the sample preparation and technical support of Donald F Smith and Karen Romine. Our thanks also to those contributors of samples who supplied descriptions for inclusion in this list.

\section{SAMPLE DESCRIPTIONS}

\section{ARCHAEOLOGIC SAMPLES}

\section{Alabama}

\section{Green County series}

Samples from Green Co, W central Alabama, on the Mississippi border.

UGa-897. 1 Gr 2

$995 \pm 75$

Charcoal from large cylindrical pit, $0.7 \mathrm{~m}$ below surface in shell midden with sherds of Saltillo Fabric Impressed, few Furrs Cord Marked, Porter Zone Incised. On Tombigbee R (34 $\left.55^{\prime} \mathrm{N}, 88^{\circ} 11^{\prime} \mathrm{W}\right)$.

UGa-898. 1 Gr 2

$1450 \pm 75$

Charcoal from $0.3 \mathrm{~m}$ deeper than $\mathrm{UGa}-897$ in same pit.

\section{Randolph County series}

Samples from several sites in Randolph Co, NE Alabama, on the Georgia border.

\section{UGa-934. 1 Ra 12}

Charcoal from Feature 1, a hearth in Zone D, a layer containing Late Archaic artifacts. Site is a rock shelter in W Randolph Co (33 $\left.21.5^{\prime} \mathrm{N}, 85^{\circ} 37^{\prime} \mathrm{W}\right)$.

UGa-1112. 1 Ra 28

$800 \pm 70$

Charcoal from mass of charred wood in Level 2,10 to $20 \mathrm{~cm}$ from 
site on Little Tallapoose R $\left(33^{\circ} 20^{\prime} \mathrm{N}, 85^{\circ} 30^{\prime} \mathrm{W}\right)$. Level dominated by ceramics of Lamar period.

\section{UGa-900. I Ra 24}

$490 \pm 110$

Charcoal underlying plow zone at depth $35 \mathrm{~cm}$ in Burial 1 pit and overlying large fragment of Lamar Complicated Stamped vessel. Site is on E bank on Tallapoosa R $\left(85^{\circ} 35^{\prime} \mathrm{N}, 33^{\circ} 16^{\prime} \mathrm{W}\right)$.

\section{UGa-1113. 1 Ra 24}

$$
685 \pm 135
$$

AD 1265

Charcoal from mass of charred wood in pit fill of Burial 2. Assoc ceramics place it within Lamar occupation. Site on Tallapoosa $\mathrm{R}$ at Hunter's Bottoms $\left(85^{\circ} 40^{\prime} \mathrm{N}, 33^{\circ} 18^{\prime} \mathrm{W}\right)$.

UGa-112, -1113 dates are early Lamar period. All dates are as expected. Alabama samples coll and described by D L DeJarnette, Mound State Mus, Moundville, Alabama.

\section{California}

\section{Ventura Mission Plaza site series}

Ven-87 is W of Mission San Buenaventura, Main St, Ventura, Ventura Co, California $\left(34^{\circ} 16^{\prime} 50^{\prime \prime} \mathrm{N}, 119^{\circ} 17^{\prime} 48.5^{\prime \prime} \mathrm{W}\right)$.

\section{UGa-916. Shell (Tivela stultorum)}

$$
3355 \pm 70
$$

\section{UGa-917. Shell (Tivela stultorum)}

These 2 shells are from depth $2 \mathrm{~m}$, UGa-917 2m N of UGa-916. Original surface may have sloped from $\mathrm{N}$ to $\mathrm{S}$, accounting for difference in ages. UGa-916 is more directly beneath a secondary hearth below a large rock feature.

\section{UGa-1024. Shell (Tivela stultorum)}

$3070 \pm 70$

\section{UGa-1025. Shell (Protothaca staminea)} $1120 \mathrm{BC}$

The two above samples are from a test trench below a Chumash Indian midden at a depth of $2.5 \mathrm{~m}$ and in contact with riverine sands.

\section{UGa-1117. Pinniped bone}

$$
\begin{aligned}
& 2305 \pm 140 \\
& 355 \text { BC }
\end{aligned}
$$

Bone of sea mammal from depth $2.05 \mathrm{~m}$ below surface from top of rock-lined earth oven. Date is reasonable for Canalino hunting of sea mammals. Comment (RSG): Ventura Mission Plaza site was occupied from ca $3500 \mathrm{BP}$, an Aboriginal (pre-contact) occupation to the historic occupation of Mission lands. Presumably the early samples are from the Indian village known in Chumash as Mitz-khlan-a-kan and renamed La 
Asuncion de Nuestra Señora by Fr Crespi, Spanish missionary. Coll by

Roberta S Greenwood, Mission Plaza Archaeol Proj, Ventura, Calif.

\section{Colorado}

\section{UGa-993. Bradford House II bone}

$2440 \pm 185$

Sec of spinal cord from burial pit of $5 \mathrm{Jf} 32\left(39^{\circ} 36^{\prime} \mathrm{N}, 105^{\circ} 10^{\prime} 29^{\prime \prime}\right.$ $\mathrm{W})$, at depth $2.3 \mathrm{~m}$ beneath a rock shelter. Coll and subm by Douglas M Medina, Aurora, Colo.

\section{Burke site series}

Site $5 \mathrm{Rb} 123$ is on right bank of Piceance Creek ca $17.7 \mathrm{~km}$ upstream from juncture with White $\mathrm{R}$ in Rio Blanco Co $\left(39^{\circ} 53^{\prime} 13^{\prime \prime} \mathrm{N}\right.$, $\left.108^{\circ} 15^{\prime} 6^{\prime \prime} \mathrm{W}\right)$.

\section{UGa-1045. Charcoal}

$$
1575 \pm 135
$$

From ash and charcoal concentration $3 \mathrm{~cm}$ thick, $121 \mathrm{~cm}$ below datum. A single hammerstone was found in this layer, overlain by sherds of plain gray pottery and a single notched projectile point coll by $\mathrm{G} A$ Bair.

\section{Boxelder Creek series}

Samples taken as part of survey along Boxelder Creek $\left(40^{\circ} 56^{\prime} \mathrm{N}\right.$, $\left.105^{\circ} 11^{\prime} \mathrm{W}\right)$, a tributary of the $\mathrm{N}$ branch of the Cache La Poudre $\mathrm{R}$ which runs into the S Platte R.

\section{UGa-810. 5 Lr 257}

$60 \pm 100$

Charcoal from hearth eroding out of $\mathbf{E}$ bank of creek.

\section{West Bank Samples 5 Lr 263}

\section{UGa-812. Charcoal}

Charcoal from hearth exposed in backhoe test.

\section{AD 1890}

\section{UGa-816. Charcoal}

$1370 \pm 175$

\section{AD 580}

Charcoal from hearth related to first culture-bearing level, assoc with many flakes, both large and retouch, glass beads, clay pine fragments, possible brass fragment, side scraper, and various bone fragments, depth $4 \mathrm{~cm}$.

\section{UGa-813. Charcoal}

$$
210 \pm 95
$$

Charcoal from hearth at $18 \mathrm{~cm}$ depth on $\mathrm{W}$ bank of creek.

\section{UGa-814. Charcoal} $420 \pm 80$

Charcoal related to 3rd culture-bearing level, assoc with some bone and many flakes, depth $20 \mathrm{~cm}$. 


\section{UGa-818. Charcoal}

$1675 \pm 85$

Charcoal from rock-lined basin-shaped hearth with large piece of charcoal remaining. It is the deepest definite hearth found at site, $110 \mathrm{~cm}$ below surface. Comment (EAM): except for UGa-810 from W bank which is either contaminated or dates recent sheep camp overlying site, the other dates, from the $\mathrm{E}$ bank, fit the expectations based on artifacts and stratigraphy very well. Coll and subm by E A Morris, Dept Anthrop, Lab Public Archaeol, Colorado State Univ, Fort Collins.

\section{Dipper Gap site series}

Site $5 \mathrm{Lg} 101$, Logan Co $\left(40^{\circ} 54^{\prime} \mathrm{N}, 103^{\circ} 33^{\prime} \mathrm{W}\right)$. Samples were isolated fragments in $\mathrm{D}$ Layer at site assoc with projectile points, bifaces, side and end scrapers, flakes worked bone and rough grinding stones corresponding to the Plains Archaic-Early Middle period, McKean cultural affiliations.

UGa-453. Charcoal from Feature 5

From fill around hearth, $1 \mathrm{~m}$ below surface.

\section{UGa-455. Charcoal from Feature 10}

From fill around hearth, .5m below surface.

\section{UGa-456. Charcoal}

Fragments from $\mathrm{D}$ layer sec, $1.5 \mathrm{~mm}$ diam, .2m deep.

Samples subm by Elizabeth Morris and coll by M D Metcalf, Colo State Univ Archaeol Field School, Dept Soc \& Anthropol, Colorado State Univ, Fort Collins, Colorado. Comment (EAM): dates consistent with expected results.

\section{UGa-661. Charcoal from Merino bison kill, $\quad 2945 \pm 1475$ $5 \mathrm{Lg} 122$ \\ 995 BC}

Very small sample from disturbed hearth material in redistributed Bison bone deposit on edge of South Platte R, (103 $\left.21^{\prime} \mathrm{W}, 40^{\circ} 28^{\prime} \mathrm{N}\right)$. Artifacts include scrapers and bifaces which are not specific in age or cultural affiliations. Coll and subm by E A Morris. Comment (EAM): date as expected.

\section{Spring Gulch site series}

Spring Gulch series 5 Lr 252, Livermore, Colorado $\left(40^{\circ} 51^{\prime} \mathrm{N}, 105^{\circ}\right.$ $12^{\prime} 30^{\prime \prime} \mathrm{W}$ ), a stratified site.

\section{UGa-664. Feature 6, Level II}

$1075 \pm 135$

Charcoal from one of several high hearths in Level II. 
UGa-669. Feature 7, Level III

Charcoal from one of lower hearths in Level III.

$1315 \pm 70$

UGa-670. Feature 5, Level III AD 635

Charcoal from one of higher hearths in Level III.

$2830 \pm 135$

UGa-671. Feature 10a, Level IV

880 BC

Charcoal from lowest hearth excavated in Level IV.

$3095 \pm 75$

UGa-672. Feature 8, Level IV

$1145 \mathrm{BC}$

Charcoal from hearth in deepest level excavated.

$1705 \pm 70$

\section{UGa-673. Feature 3, Level III}

AD 245

Charcoal from upper portion of Level III hearth.

UGa-829. Feature 3, Level III

$465 \mathrm{BC}$

Charcoal from hearth in lower portion of Level III. Comment (EAM): dates consistent with expected results. Coll and subm by E A Morris.

\section{Indiana}

UGa-823. Harrison Co site, 12 Hr 103

$4400 \pm 185$

2450 BC

Bone from features of mussel shell (pits) which extend into sterile clay $\left(86^{\circ} 00^{\prime} 15^{\prime \prime} \mathrm{N}, 38^{\circ} 00^{\prime} 01^{\prime \prime} \mathrm{W}\right)$. Comment (DEJ): sample not originally coll for ${ }^{14} \mathrm{C}$ age determination and was washed in water only. Archaic date, ca $2700 \mathrm{BC}$ is expected. Coll and subm by D E Janzen, Dept Anthropol, Centre Coll, Danville, Kentucky.

\section{Kansas}

UGa-381. Elliott site

$$
1935 \pm 75
$$

Charcoal hearth in midden of $14 \mathrm{Ge} 312\left(39^{\circ} 2^{\prime} \mathrm{N}, 96^{\circ} 37^{\prime} \mathrm{W}\right)$, Geary Co, Kansas. Hearth has Woodland component and site has Schultz focus traits. Comment (PJO'B): date is earlier than expected, but not impossible (O'Brien et al, 1973).

UGa-382. Coffey site

Charcoal from Feature 11 hearth, Zone B, 3rd of 7 stratigraphic layers separated by sterile soil at Coffey Site 14 Po $1\left(39^{\circ} 34^{\prime} \mathrm{N}, 96^{\circ} 34^{\prime}\right.$ W), at Pottawatomie-Marshall Co border. Materials in Zone A above Zone B are related to Grove focus in NE Oklahoma and Calf Creek in NW Arkansas. These are thought to be Middle or late Early Archaic and the date fits well (O'Brien et al, 1973). 


\section{Griffing site series}

Site 14 Ry $401\left(39^{\circ} 11^{\prime} \mathrm{N}, 96^{\circ} 36^{\prime} \mathrm{W}\right)$.

\section{UGa-465. Charcoal}

AD 1090

From Feature 20, trash storage pit in floor of house.

\section{UGa-828. Charcoal}

$810 \pm 60$

From same feature as UGa-465.

\section{UGa-827. Charcoal}

AD 1280

$670 \pm 60$

From Feature 19, storage pit. Comment (PJO'B): 5 GaK dates (144650 unpub) range from 250 to 280 BP but 860 BP agrees with sites on the Blue (Johnson, 1973) and Republic (Witty, 1963) Rivers. Kansas samples coll and subm by P J O'Brien, Dept of Soc and Anthropol, Kansas State Univ, Manhattan.

\section{Kentucky}

Spencer Co 15 Sp 5 site series

$\left(85^{\circ} 25^{\prime} 56^{\prime \prime} \mathrm{N}, 38^{\circ} 01^{\prime} 29^{\prime \prime} \mathrm{W}\right)$.

UGa-837. Charcoal, Units 1 and 2, Feature 1

$1215 \pm 55$

Charcoal assoc with trash pit (bone and shell tempered pottery). Comment (DEJ): date should be ca AD 1300.

\section{UGa-838. Charcoal}

$600 \pm 75$

Charcoal assoc with Burial 3. Comment (DEJ): date should be ca AD 1300 or later.

\section{UGa-839. Charcoal}

$$
1020 \pm 60
$$

Sample derived from large circular pit, ca $4.58 \mathrm{~m}$ diam containing bone and shell tempered pottery. The feature was covered with 5 layers of limestone slabs. No burial was assoc with the feature and its meaning is unknown.

\section{UGa-840. Bone}

$$
680 \pm 80
$$

Sample's occurrence and history same as UGa-839. Subm to make comparison of this date with the date derived from charcoal sample. Coll and subm by D E Janzen, Dept Anthropol, Centre Coll, Danville, Kentucky.

\section{Coons site series}

\section{Missouri}

Coons site 23 Pl $16\left(38^{\circ} 12^{\prime} \mathrm{N}, 94^{\circ} 43^{\prime} \mathrm{W}\right)$ at mouth of Brush Creek, Platte Co, Missouri. 
UGa-392. Charcoal

From plow zone-mix boundary of House 1 .

UGa-466. Charcoal

Fill above House 1 floor.

UGa-467. Charcoal

From Feature 1B, a storage trash pit under fireplace of House 1.

\section{UGa-375. Charcoal}

$1180 \pm 110$

From same location as UGa-467.

Samples coll and subm by $\mathrm{P}$ J O'Brien, Kansas State Univ, Manhattan, Kansas. Comment (PJO'B): house dates are consistent with expectations, but pit dates are too early as charcoal was assoc with a Cahokian Ramey Incised sherd dating ca AD 1100.

\section{James River Basin Archaeological Project series}

UGa-886. Ingram site

AD 1200

$750 \pm 105$

Charcoal from Level 2 at $23 \mathrm{Gr} 303\left(37^{\circ} 9^{\prime} \mathrm{N}, 93^{\circ} 12^{\prime} \mathrm{W}\right)$ assoc with a non-ceramic Woodland horizon.

UGa-887. Indian Cave-1

$775 \pm 70$

\section{AD 1175}

Charcoal from Level 9 at $23 \mathrm{~Wb} 60\left(37^{\circ} 12^{\prime} \mathrm{N}, 93^{\circ} 1^{\prime} \mathrm{W}\right)$ assoc with grit and crushed limestone sherds of a Woodland period occupational horizon.

\section{UGa-888. Indian Cave-1}

$760 \pm 70$

Charcoal from Level 10, same site and assoc as UGa-887.

\section{UGa-889. Turner Station site}

$1325 \pm 130$

Charcoal from post mold at $23 \mathrm{Gr} 10 \mathrm{~A}\left(37^{\circ} 11^{\prime} \mathrm{N}, 93^{\circ} 10^{\prime} \mathrm{W}\right)$ assoc with Late Archaic-Early Woodland material. Comment (MJF): dates as expected. Coll by Michael J Fuller and subm by Robert Cooley, Southwest Missouri State Univ, Springfield.

\section{North Carolina}

\section{UGa-1086. Jordan's Landing}

$525 \pm 70$

Charcoal from $31 \mathrm{Br} 7$, Berties Co, North Carolina $\left(35^{\circ} 53^{\prime} 15^{\prime \prime} \mathrm{N}\right.$, $\left.76^{\circ} 55^{\prime} 30^{\prime \prime} \mathrm{W}\right)$ from intact cooking pit with assoc ceramic ladle, bone fish hook, fish and mussel remains, also hickory nut fragments and seeds. Sample coll from bottom of pit around quartzite fire stones. Ceramic 
assocs indicate late Tuscarora occupation and date agrees. Coll and comment by D S Phelps.

\section{UGa-1085. Baum site}

$$
1590 \pm 65
$$

Charred juncus grass fragments of woven grass mat upon which lay a cremated burial. This burial partly intruded into an ossuary containing 58 persons. Both date from the late Algonkian occupation of the site. Assoc ceramics are shell tempered. Date is much earlier than expected. Coll and comment by D S Phelps.

\section{UGa-1089. Baum site}

$$
635 \pm 70
$$

Oyster from midden covering site, contains shell tempered ceramics. Baum site $31 \mathrm{Ck} 9$ is in Currituck Co, North Carolina $\left(36^{\circ} 17^{\prime} 40^{\prime \prime} \mathrm{N}\right.$, $75^{\circ} 53^{\prime} 20^{\prime \prime} \mathrm{W}$ ). Coll by D S P and R W Anthony. Comment (DSP): age is reasonable.

\section{UGa-1090. Kitty Hawk Bay site}

Oyster shell from 31Dr 14, Collington I., Dare Cio, North Carolina $\left(36^{\circ} 01^{\prime} 20^{\prime \prime} \mathrm{N}, 75^{\circ} 43^{\prime} 12^{\prime \prime} \mathrm{W}\right)$, basal level of shell midden at high point of island, $+12 \mathrm{~m}$. Assoc with shell tempered ceramics. Site C 3 in Haag (1958). Collected by R Bunn.

\section{UGa-1088. Rush Point site}

$1685 \pm 65$

\section{5}

Oyster shell from 31Dr 15, Collington I. $\left(36^{\circ} 01^{\prime} 20^{\prime \prime} \mathrm{N}, 75^{\circ} 43^{\prime} 45^{\prime \prime}\right.$ W) from basal level of midden $30 \mathrm{~cm}$ deep on ridge at $+5 \mathrm{~m}$, assoc with sand and grit tempered ceramics. Coll by J G Justice and D S P.

\section{UGa-1087. White Court site}

$$
720 \pm 65
$$

Oyster shell from 31Dr 33, Collington I. (36 $0^{\prime} 21^{\prime \prime} \mathrm{N}, 75^{\circ} 43^{\prime} 20^{\prime \prime}$ W) $20 \mathrm{~cm}$ deep in a refuse pit. Coll by $\mathrm{T}$ Gardner. Comment (DSP): context indicates age should be about contemporaneous with Kitty Hawk Bay site sample.

The above North Carolina samples subm by D S Phelps, Dept Soc \& Anthropol, East Carolina Univ, Greenville, North Carolina.

$$
\text { Oregon }
$$

UGa-1003. North Mound, Neah-Kah-Nie Mt

Charcoal from filled pit over which a small stone mound was built $\left(45^{\circ} 44^{\prime} 30^{\prime \prime} \mathrm{N}, 123^{\circ} 75^{\prime} \mathrm{W}\right)$. Comment: date is somewhat early to support theory that this was a survey marker built by Spanish explorers in 1579 . Coll and comment by M W Jensen, Jr, Tillamook, Oregon. 


\section{UGa-819. Camp Cangaru site, N Colombia}

midden on Isla de Salamanca, a vegetated Cultural affilianta Marta on N coast of Colombia $\left(11^{\circ} \mathrm{N}, 74^{\circ} 33^{\prime} \mathrm{W}\right)$. late cultures of lower Magdalencertain but appears related to relatively Date is rearta. Date is reasonable. Coll by Carson N Murdy, Peace Corps, and subm by Donald R Sutherland, Dept of Anthropol, Univ South Carolina, Columbia.

\section{REFERENCES}

Greenwood, R S, 1974, San Buenaventura Mission Plaza Project Archaeological Report: 3500 years on one city block. Redevelopment Agency, Ventura, California 93001,484 p.

Haag, W G, 1958, Archaeology of coastal North Carolina, Louisiana State University Coastal Studies, ser no. 2, Baton Rouge, $120 \mathrm{p}$

Johnson, A E, 1973, Archaeological investigations at the Budenbender site Turtle Creek Reservoir, North Central Kansas, 1957: Plains Anthropologist, Topeka,
v 18, no. 62, p 271-299.

O'Brien, P J, 1973, A most preliminary report of the Coffey site 14 Pol; a Plain Archaic site in Pottawatomie County, Kansas: Kansas Anthropol Assoc Newsletter, Topeka, v 18, no. 5, p 1-38.

O'Brien, P J, et al, 1973, The Elliott site (14Ge 303), a preliminary report: Plains Anthropologist, Topeka, v 18, no. 59, p 54-72.

Witty, T A, Jr, 1963, The Woods, Avery and Streeter Archaeological sites, Milford Reservoir, Kansas: Kansas State Hist Soc Anthropol ser, no. 2, Topeka, 73 p. 